\title{
Same same but different: ecological niche partitioning of planktonic freshwater prokaryotes
}

\author{
Michaela M. SALCHER* \\ Limnological Station, University of Zurich, Seestrasse 187, 8802 Kilchberg, Switzerland \\ *Corresponding author: msalcher@limnol.uzh.ch
}

\begin{abstract}
Lakes and ponds harbour a high number of diverse planktonic microorganisms that are centrally involved in biochemical cycles and aquatic food webs. Although the open water body (pelagial) seems to be a uniform and unstructured environment, ecological niche separation of coexisting microbial taxa might be triggered by limiting resources (bottom-up control) and mortality factors (top-down control), leading to distinct spatial and temporal distribution patterns of different microbes. This review gives an overview of the most abundant prokaryotic populations by grouping them in specific ecological guilds based on their life strategies. Defense specialists such as very small Actinobacteria or big filamentous bacteria mostly occur at times of highest grazing pressure by heterotrophic nanoflagellates, the main consumers of bacteria. Oligotrophic ultramicrobacteria, on the other hand, seem to be mostly adapted to nutrient depleted water layers during summer stratification, while opportunistic bacteria profit from material released during short-living algal blooms. Seasonal changes in abiotic and biotic factors may be the main causes for periodic reoccurring density maxima of different prokaryotes populations in the pelagial of temperate lakes, reflected in a distinct seasonality of the freshwater bacterioplankton.
\end{abstract}

Key words: ecological niche, freshwater bacterioplankton, seasonality, spatial patchiness, bottom-up control, top-down control.

Received: June 2013. Accepted: July 2013.

\section{PELAGIAL OF LAKES AND PONDS AS HABITAT FOR MICROBES}

Freshwater microorganisms occur in high numbers and comprise an enormous genetic diversity: one $\mathrm{mL}$ of lake water contains approximately $10^{6}$ prokaryotic cells (range: $10^{5}-10^{7} \mathrm{~mL}^{-1}$ ) and several thousand microbial genotypes (Newton et al., 2011). While Eukarya (including animals and plants) represent only a small branch in the tree of life (Fig. 1) and are limited to a handful of nutritional modes, Bacteria and Archaea encompass virtually all genetic diversity and lifestyles. Moreover, lacustrine microorganisms possess key functions in all biochemical cycles and are therefore crucial for the functioning of lakes. The recycling of dissolved organic matter by microbes via the classical microbial loop and the channelling of carbon to higher trophic levels is the necessary basis of every aquatic food web (Azam et al., 1983; Pomeroy, 1974; Sherr and Sherr, 1988).

Prokaryotes inhabit virtually every zone in lakes in the benthal (litoral and profundal) and pelagial, and special microbial habitats can be found at the boundary regions to air (neuston) and sediment, and at the surfaces or inside eukaryotes (animals, plants, and protists). Microorganisms in the pelagic realm of lakes and ponds can either live planktonic or attached to particles (lake snow) and many microbes can even switch from one lifestyle to the other (Grossart, 2010). This review focuses on the permanently free-living fraction of freshwater bacterioplankton in the oxygenated water body of temperate lakes and the differential microbial life strategies that can be found in such a seemingly unstructured and uniform environment. Niche separation of coexisting microbial populations triggered by growth and mortality factors may result in distinct ecological guilds of prokaryotes. Members of such guilds are frequently unevenly distributed in the pelagial, both on spatial (longitudinal as well as vertical) and temporal scales (i.e., seasonality). Together with additional metabolic diversification of sympatric microbial populations (i.e., resource partitioning and cross-feeding), this niche separation might be an explanation for the high diversity of pelagic microbes, analogous to Hutchinson's paradox of the plankton for phytoplankton (Hutchinson, 1961).

Niche partitioning of micro- and macroorganisms has already been intensely investigated in experiments focusing on the emergence and maintenance of species diversity (Gómez and Buckling, 2013; Lawrence et al., 2012; Rainey et al., 2000; Rainey and Travisano, 1998). Spatially structured environments were identified as important drivers for genetic diversification of microbes (Rainey and Travisano, 1998), as well as resource partitioning and cross-feeding on waste products of co-occurring species (Lawrence et al., 2012). Moreover, spatio-temporal niches in experimental river biofilms have not only led to higher algal diversity but also to increased nutrient elimination and thus, improved water quality (Cardinale, 2011). Such examples of spatially, 
seasonally, and physiologically driven niche separation in experimental systems might point at selective processes that led to the high diversity observed today. However, as many experimental studies focused on a few well-known model organisms (Rainey and Travisano, 1998; Turner et al., 1996), a propagation of results to the pelagial of freshwater lakes is challenging. Here, numerous microbial taxa with largely unknown physiological capacities co-occur and we just started to get a glimpse of the overall biodiversity and the multitude of interplaying factors shaping freshwater microbes.

\section{FACTORS SHAPING MICROBIAL GROWTH AND SURVIVAL IN THE PELAGIAL}

Two key factors control microbial abundances in aquatic habitats: firstly, bacterial growth is limited by competition for available resources (bottom-up control) as well as by physical factors like temperature, $\mathrm{pH}$, oxy- gen, and light. Secondly, mortality is caused by grazing and viral lysis (top-down control). In lakes, top-down and bottom-up control have numerous complex interactions in situ and tend to co-occur (Grossart et al., 2008; Salcher et al., 2007; Šimek et al., 2008).

All microbes are dependent on limiting resource of the dissolved organic matter (DOM) pool that consists of various different substances. The main components supporting microbial growth are simple mono- and oligomers like amino acids, carbohydrates, and carboxylic acids that are only present in $\mathrm{nM}$ concentrations in natural lake water (Meon and Jüttner, 1999; Zotina et al., 2003) with fast turnover rates (Rosenstock and Simon, 1993; Sundh, 1992). Phytoplankton and cyanobacterial blooms are main sources of labile DOM as algae release a substantial fraction of exudates (Callieri et al., 2007; Hama and Handa, 1987). Although the majority of exudates are polymers (Giroldo and Vieira, 2005), microbes utilize algal low molecular weight

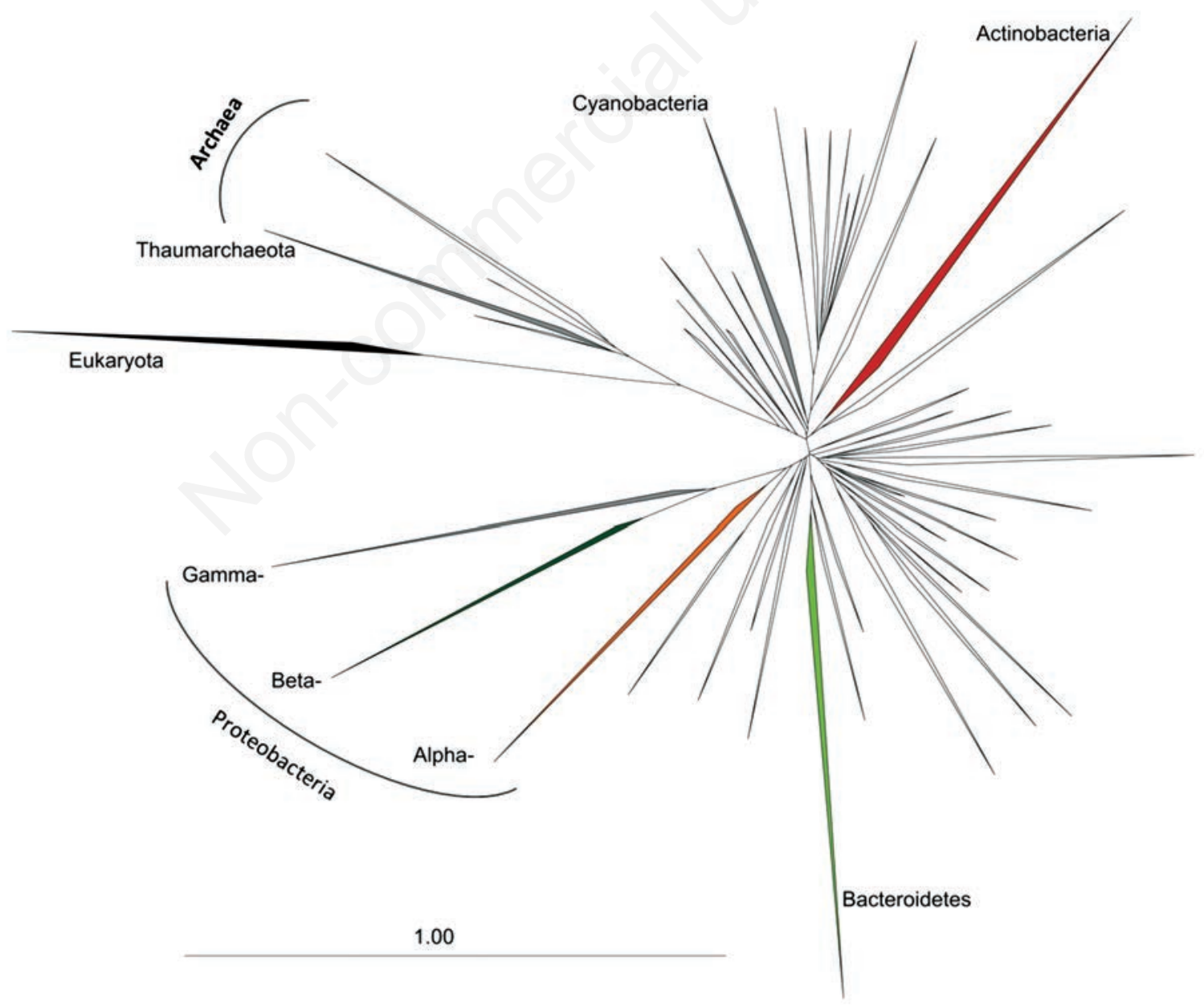

Fig. 1. Phylogenetic tree of the $16 \mathrm{~S}$ rDNA of typical freshwater prokaryotes (including a branch of Eukaryota based on $18 \mathrm{~S}$ rDNA). Phyla with populations further described in the text are highlighted. 
(LMW) exudates more rapidly and to a much higher extent (Giroldo et al., 2007). Moreover, some bacteria are specialized in the breakdown of algal polymers to small monomers that can be subsequently utilized by other microbes (Williams et al., 2013). Allochthonous DOM input from terrestrial sources can be also an important carbon source for freshwater microbes, especially in small humic lakes with large catchment areas or short water retention times (Berggren et al., 2010; Kritzberg et al., 2004). Although this DOM type is considered to be a poor substrate for bacteria because of chemical recalcitrance, the higher amounts of DOM present in humic lakes might compensate for low degradation rates (Wetzel, 2001). Moreover, humic substances can be photochemically degraded to more bioavailable substrates such as carboxylic acids (Berggren et al., 2010; Bertilsson and Tranvik, 1998).

Several excellent reviews deal with top-down control of the bacterioplankton by protistan grazing (Hahn and Höfle, 2001; Jürgens and Matz, 2002; Pernthaler, 2005; Pernthaler and Posch, 2009), and viral lysis (Weinbauer, 2004; Winter et al., 2010). The main consumers of freshwater microbes are small protists such as flagellates and ciliates, however, also cladocerans and rotifers may occasionally graze on larger morphotypes such as filamentous bacteria (Lampert, 2006; Langenheder and Jürgens, 2001; Pernthaler et al., 2004; Sanders et al., 1989). Heterotrophic nanoflagellates (HNF) typically dominate grazing with ingestion rates of up to $77 \%$ of the daily bacterial production (Sanders et al., 1989). Grazing by protists is predominately affecting medium-sized bacteria, as most flagellates and small ciliates are size selective (Andersson et al., 1986; Chrzanowski and Šimek, 1990; Jürgens and Matz, 2002; Posch et al., 2001), while very small cells and filamentous bacteria seem to be protected from ingestion (Pernthaler, 2005; Posch et al., 1999). Viral-induced mortality also accounts for a significant, however, highly variable fraction of bacterial production in freshwaters (Weinbauer, 2004). Viral abundances are usually at least one order of magnitude higher than bacterial numbers and seasonally tightly coupled (Personnic et al., 2009; Pradeep Ram et al., 2010; Thomas et al., 2011). As phage infection is host density dependent, viruses mostly affect competitive and highly abundant microbes, and thus, may even sustain species diversity by killing the winner (Thingstad and Lignell, 1997; Winter et al., 2010). Moreover, viral lysis leads to a significant release of DOM, in turn stimulating microbial growth (Weinbauer, 2004).

\section{COMMON BACTERIOPLANKTON TRIBES IN FRESHWATERS}

Lakes and ponds harbour a high diversity of microbial species, however, most of them still lack cultured representatives (Hahn, 2006; Newton et al., 2011). Cultivation-independent in situ analyses based on the 16S rRNA gene as phylogenetic marker are therefore useful tools to assess gross microbial diversity (fingerprinting methods) and identity (phylogenetic analyses), and to quantify distinct populations (fluorescence in situ hybridization (FISH) techniques, qPCR). High-resolution next-generation sequencing (454 pyrosequencing of short fragments of the $16 \mathrm{~S}$ rDNA) commonly resulted in $>1500$ OTUs (operational taxonomic units at a cut-off of $97 \%$ sequence similarity, i.e., different species) in the epilimnion of freshwater lakes (Eiler et al., 2012; Peura et al., 2012b) and even $>3500$ OTUs if hypoxic hypolimnia were included (Peura et al., 2012a). However, as aquatic microbial communities are dominated by a few very abundant lineages and a high number of rare taxa, the real microbial diversity might be substantially higher (Pedrós-Alió, 2012). Moreover, all PCR based approaches for estimating microbial diversity are vulnerable to possible biases introduced during DNA isolation (Frostegard et al., 1999), PCR amplification (Wintzingerode et al., 1997), and an irregular number of 16S rRNA genes per cell (Farrelly et al., 1995). In an excellent review by Newton et al., (2011), >100 ubiquitous freshwater bacterial tribes (i.e., monophyletic OTUs gained from at least 2 lakes) were identified. Such tribes, however, might include different subspecies or ecotypes, e.g., the prominent Betaproteobacteria Polynucleobacter and Limnohabitans harbour ecotypes beneath the species level that differed in habitat preference, pointing to pronounced ecological micro-diversification (Jezbera et al., 2011, 2013). Moreover, further sequencing and subsequent quantitative analyses by e.g., FISH might still lead to the detection of novel ubiquitous freshwater tribes and might help to unravel ecological properties of so far poorly studied populations, as was recently demonstrated for e.g., Chloroflexi (Okazaki et al., 2013) or the LD12 tribe of Alphaproteobacteria (Fig. 2; Salcher et al., 2011b). Most studies have focussed on the identification, quantification, and the assignment of a potential ecological role of the most abundant microbial taxa in freshwaters, while rare species remain still widely unexplored (Pedrós-Alió, 2012). Members of the rare biosphere might be dormant most of the time acting as seed banks (Lennon and Jones, 2011; Williams et al., 2013), to enable a rapid recruitment of species in response to environmental changes (e.g., as degraders of specific short-living organic matter compounds). Such a contribution to compensatory dynamics of different species might be crucial for the overall stability of microbial communities (Fig. 3). Some studies suggest that rare species are disproportionally active and get selectively ingested by grazers, and thus, might act as an important link of carbon flow to higher trophic levels (Jones and Lennon, 2010; Zeder et al., 2009) .

Typically, the most abundant planktonic freshwater prokaryotes (Fig. 1) are affiliated with the phyla Actinobacteria, Proteobacteria (mainly of the alpha- and 
beta-subdivision), Bacteroidetes (Flavobacteriales and Sphingobacteriales), Cyanobacteria, Verrucomicrobia, Thaumarchaeota, and a handful of others are present in low or transient abundances (i.e., Acidobacteria, Chlorobi, Chloroflexi, Fibrobacteres, Firmicutes, Fusobacteria, Gemmatimonadetes, Lentisphaerae, Nitrospira, Planctomycetes, Spirochaetes, and members of the uncultured phyla BRC1, OD1, OP10, SR1, and TM7).

\section{DIFFERENT LIFE STRATEGIES OF LACUSTRINE BACTERIOPLANKTON POPULATIONS}

Because of the enormous diversity of pelagic microbes, I will focus on some of the most abundant and well-studied populations and try to identify reasons for their success (i.e., their specific niches) in freshwaters. A comprehensive de-
A: Piburger See, Austria

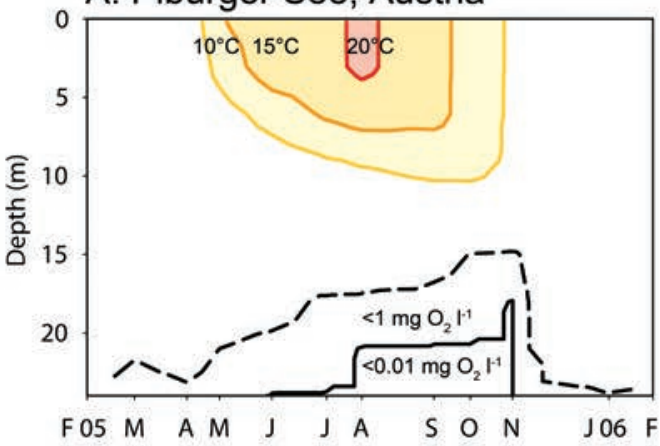

C:

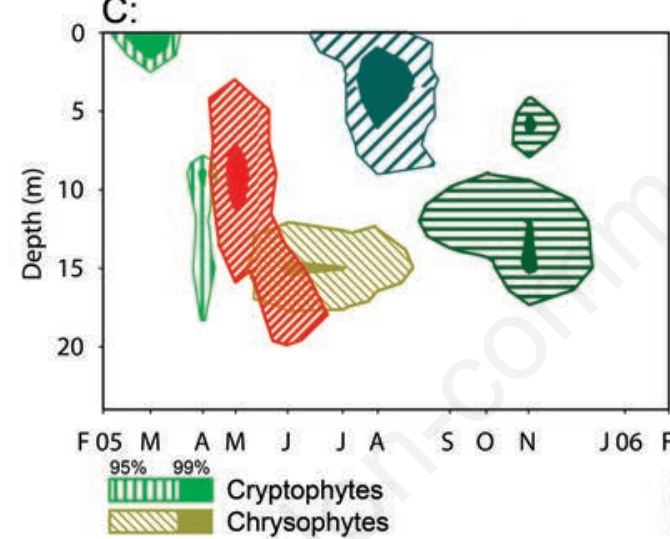

E:

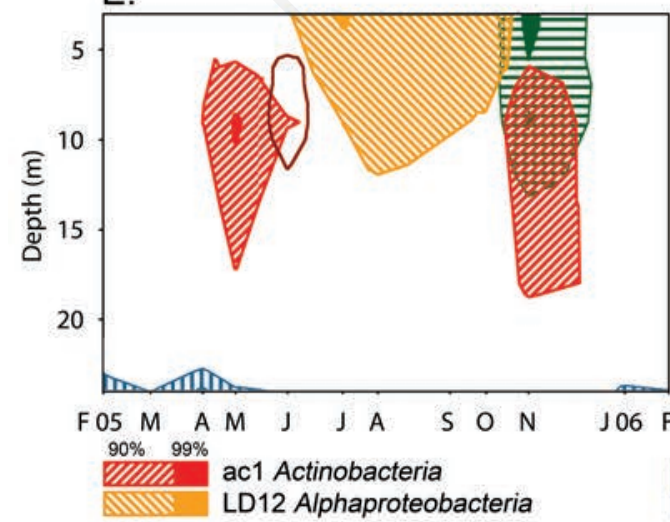

B: Lake Zurich, Switzerland
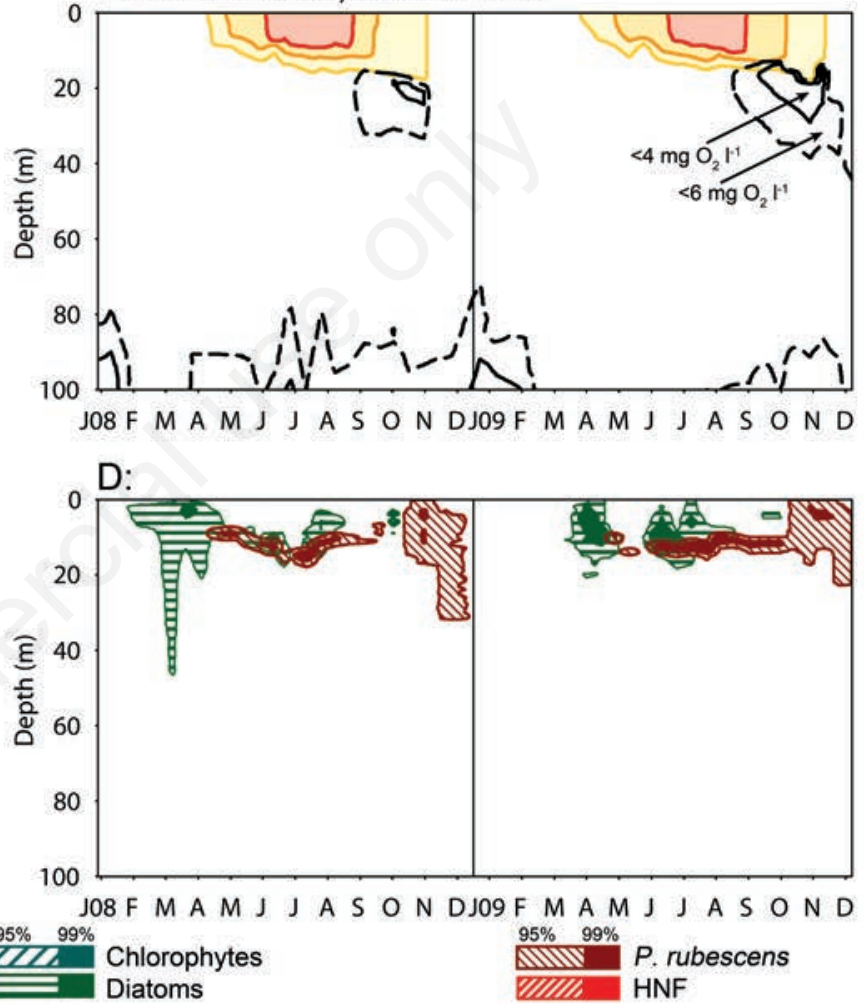

$\mathrm{F}$ :

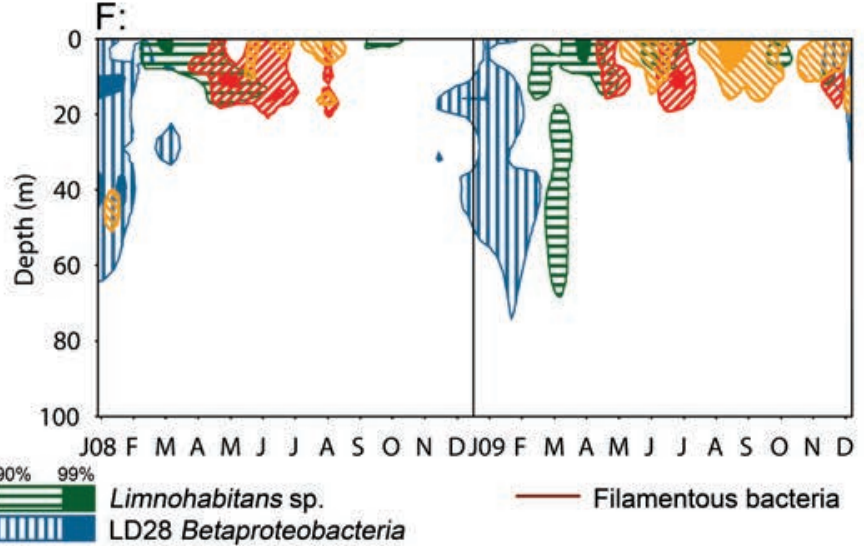

Fig. 2. Seasonal patterns of temperature, oxygen content (A,B), abundances of different algal groups, the cyanobacterium Planktothrix rubescens, heterotrophic nanoflagellates (C,D), and selected microbial populations (E,F) in Piburger See, Austria (A,C,E) and Lake Zurich, Switzerland (B,D,F). All biological data are presented as population maxima (percentiles are given in legend). Raw data were taken from Salcher et al. (2008, 2010, 2011), and unpublished data. 
scription of the life strategies of these populations, however, is still challenging. Thus, they are grouped in distinct ecological guilds based on growth patterns, survival strategies, or specific physiological adaptations.

\section{Defense specialists}

The numerically dominant microbes in freshwaters are affiliated with Actinobacteria (Glöckner et al., 2000; Zwart et al., 2002), a phylogenetically diverse phylum with 9 ubiquitous freshwater lineages and $>40$ tribes (Newton et al., 2011). The most abundant family-like lineage (ac1) can account for $>50 \%$ of microbes in the pelagial of lakes (Warnecke et al., 2005) and shows recurrent seasonal patterns with population maxima in spring and/or autumn (Fig. 2; Allgaier and Grossart, 2006; Salcher et al., 2010). The spring maxima typically occur shortly after phytoplankton blooms contemporaneous with high numbers of HNF (Eckert et al., 2012; Salcher et al., 2010; Zeder et al., 2009), pointing to specific adaptations to high grazing pressure. Freshwater Actinobacteria are of con- spicuous small cell size $\left[<0.1 \mu \mathrm{m}^{3}\right.$, i.e., ultramicrobacteria (Posch et al., 2009)], which per se might protect them from ingestion by size selective flagellates (Jezbera et al., 2006; Pernthaler et al., 2001). Even if ingested by HNF, these bacteria might not be digested, as they do not promote growth of flagellates (Šimek et al., 2013), which is related to their specific gram+ cell wall properties (Tarao et al., 2009). Moreover, ac1 Actinobacteria seem to profit from polymeric organic carbon sources released by the consumption of their grazing-vulnerable competitors (Beier and Bertilsson, 2011; Eckert et al., 2013) and are involved in carbohydrate turnover (Buck et al., 2009; Garcia et al., 2013; Salcher et al., 2013). Generally, freshwater Actinobacteria seem to have competitive disadvantages to opportunistic, fast-growing bacteria in nutrient and/or substrate enrichments; however, they can form highly persistent population numbers because of their grazing resistance (Šimek et al., 2006). Within the ac1 lineage, some taxa are better adapted to alkaline lakes, while others prefer acidic conditions (Newton et al., 2007) and even within the same lake, different tribes can occupy distinct niches

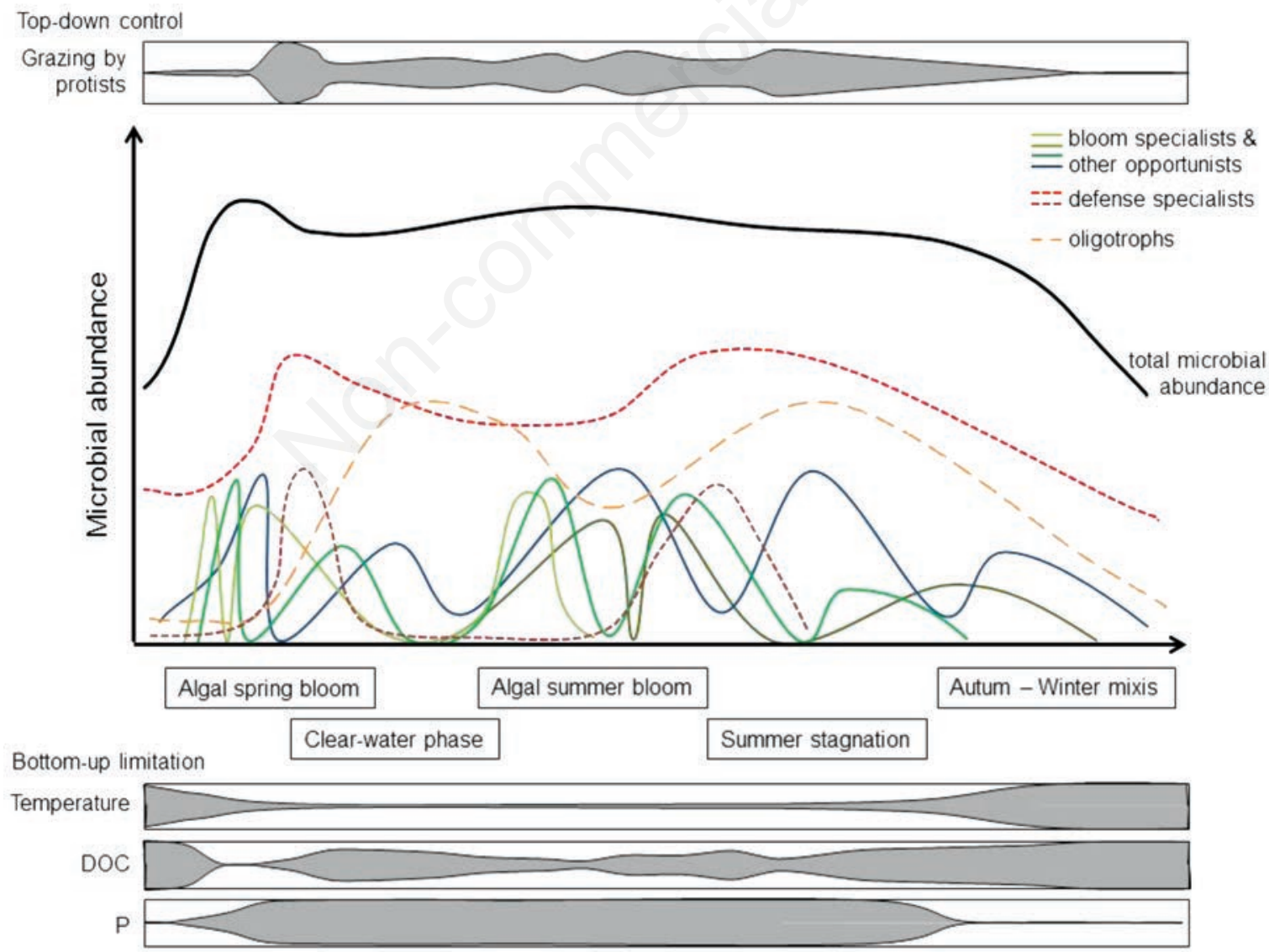

Fig. 3. Schematic view of seasonal successions of different microbial guilds in the epilimnion of lakes resulting in relatively stable total prokaryotic numbers. The main top-down and bottom-up limitations for microbes and typical seasonal phases in freshwaters are given for reference. 
according to oxygen content and substrate preferences (Allgaier and Grossart, 2006; Buck et al., 2009). So far, no pure cultures of ac1 Actinobacteria have been established; however, one representative was described as Candidatus Planktophila limnetica based on low but stable densities in co-cultures (Jezbera et al., 2009). Some members of ac1 Actinobacteria have light driven proton pumps (rhodopsins) that might be important in energy generation to fuel, e.g., membrane transporters (Garcia et al., 2013; Sharma et al., 2009; Wurzbacher et al., 2012).

A special form of defense strategy against flagellate grazing can be attributed to filamentous bacteria: threadlike cells are beyond the handling and ingestion size limit of HNF (Hahn et al., 1999; Jürgens and Stolpe, 1995; Šimek et al., 2001). Filamentous bacteria are no coherent taxonomic unit, as members of different phyla (e.g., Proteobacteria, Bacteroidetes) share this morphology (Hahn et al., 1999; Salcher et al., 2007; Schauer and Hahn, 2005). Although filaments appear to be numerically not very important, their contribution to overall microbial biomass is substantial due to their large biovolume (Corno et al., 2008; Pernthaler et al., 1998; Posch et al., 2009; Schauer et al., 2006). Some taxa are of obligate filamentous morphology [e.g., Candidatus Aquirestis calciphila (Hahn and Schauer, 2007)], while others are morphologically variable [facultative filamentous bacteria, e.g., Flectobacillus sp. (Hahn et al., 1999; Šimek et al., 2007) or Comamonas acidovorans (Hahn and Höfle, 1998)]. Such a morphological plasticity was hypothesized to be triggered by chemical cues released by predators (Corno and Jürgens, 2006). Typically, filamentous bacteria have recurrent seasonal population maxima at the decline of spring phytoplankton blooms (Fig. 2), during highest grazing pressure by HNF (Eckert et al., 2012; Jürgens and Stolpe, 1995; Pernthaler et al., 2004; Schauer et al., 2006). This timing might be related to the grazing resistance of filaments and their subsequent enrichment in the community or even to a reduced risk of viral attacks (Šimek et al., 2007). However, filamentous bacteria might also directly profit from algal exudates such as carbohydrates (Salcher et al., 2013; Schauer et al., 2006) or from recycled material released during predation on other microbes (Eckert et al., 2013). Although they seem to occupy the same niche as ac1 Actinobacteria, filamentous bacteria differ substantially in their role in the carbon flow: spring maxima of filaments are typically rapidly terminated by filter-feeding crustaceans (esp. Daphnia sp.) during the clearwater phase, as filaments are within the size range of the filter apparatus of daphnids (Langenheder and Jürgens, 2001; Pernthaler et al., 2004; Schauer et al., 2006). Hence, these bacteria represent a substantial fraction of microbial biomass that is directly transferred to higher trophic levels in bypassing the microbial loop and might therefore be an important link in the carbon flow, while Actinobacteria might be more regarded as a sink for organic carbon.

\section{Oligotrophic ultramicrobacteria}

Besides Actinobacteria, also microbes of the LD12 tribe of Alphaproteobacteria are of conspicuous small cell size and occur in high numbers in freshwater lakes (Heinrich et al., 2013; Salcher et al., 2011b). So far, there is no evidence that these ultramicrobacteria are protected from grazing by flagellates in the same way as Actinobacteria. However, their annual population maxima were in parallel with neither HNF nor Actinobacteria, pointing to a different life strategy (Fig. 2). In fact, niche separation between LD12 Alphaproteobacteria and ac1 Actinobacteria has been proposed based on spatial (Salcher et al., 2011a), temporal (Fig. 2; Eiler et al., 2012), as well as ecophysiological properties (Salcher et al., 2013). LD12 Alphaproteobacteria are the freshwater sister group of the dominant marine microbes, called SAR11 (Bahr et al., 1996; Salcher et al., 2011b; Zwart et al., 2002). The family-like SAR11 clade includes several highly diversified marine, brackish, and freshwater tribes, whereof the marine representatives have attracted most attention (Giovannoni et al., 2005a, 2005b; Morris et al., 2002). Although transitions between marine, brackish and freshwaters have been rare during the evolution of this family (Logares et al., 2010), all 3 phylotypes can co-occur in the same habitat [i.e., the coastal Baltic Sea (Herlemann et al., 2011; Piwosz et al., 2013)] and share several ecological features (Salcher et al., 2011b). Typically, LD12 Alphaproteobacteria have recurrent population maxima in the epilimnion in summer, at times of low phytoplankton biomass and nutrient availability (Heinrich et al., 2013; Salcher et al., 2011b). They follow an oligotrophic lifestyle with slow but efficient uptake of amino acids already at low substrate concentrations and are centrally involved in LMW substrate turnover (Salcher et al., 2011b). Microbes of the marine SAR11 clade are characterized by streamlined genomes that encode a high number of membrane transporters and light driven proton pumps (rhodopsins; Giovannoni et al., 2005a, 2005b). Similarly, LD12 Alphaproteobacteria seem to have reduced genomes and rhodopsins for photoheterotrophic energy acquisition (Atamna-Ismaeel et al., 2008; Bertilsson, unpublished data).

Other ubiquitous ultramicrobacteria thriving in epilimnia of lakes are affiliated with Polynucleobacter sp. (Betaproteobacteria). These bacteria (esp. P. necessarius ssp. asymbioticus) can be readily enriched (Burkert et al., 2003; Grossart et al., 2008; Hutalle-Schmelzer et al., 2010) and cultured (Hahn, 2003; Hahn et al., 2009), they have short doubling times and are actively ingested by flagellates (Hahn et al., 2012), pointing to an opportunistic life strategy. However, these microbes have a more passive lifestyle, as they do not incorporate algal exudates such as carbohydrates and are not associated with short-living algal blooms, but on the other hand specialized in the utilization of photooxidation products of humic substances, e.g., carboxylic acids (Buck et al., 2009; Hahn et al., 2012). Therefore, P.n. ssp. asymbioti- 
cus might be rather placed in the guild of oligotrophic ultramicrobacteria, as they have also very small cell sizes and streamlined genomes (Hahn, 2003; Hahn et al., 2012). Moreover, some photoheterotrophic Polynucleobacter $\mathrm{sp}$. use light as energy source (Martinez-Garcia et al., 2012).

\section{Opportunistic bacteria}

Contrary to oligotrophic bacteria, some freshwater taxa can be characterized by their fast generation times and short-lived population maxima. These so called opportunistic bacteria (also known as competition specialists, uptake specialists, growth specialists, copiotrophic bacteria, or feast and famine bacteria) are typically specialized on shortliving DOM sources (Šimek et al., 2005; Thingstad et al., 2005 ) and might also be found attached to particles (Grossart, 2010). Opportunistic bacteria may be rare in the pelagic zone (Šimek et al., 2006), however, they act as an important link in the carbon flow to higher trophic levels because of their disproportional contribution to bacterial biomass production and their tight control by bacterivorous grazers (Kasalický et al., 2013; Sherr and Sherr, 1988). Members of this bacterial guild are typically larger than ultramicrobacteria and therefore highly vulnerable to size selective grazing (Posch et al., 2009; Šimek et al., 2005; Zeder et al., 2009). This selective mortality together with a fast depletion of transient carbon and nutrient sources may limit the dominance of opportunistic bacteria resulting in short-term blooms of these taxa (Fig. 3).

Probably the best studied opportunistic taxa are affiliated with Limnohabitans (Betaproteobacteria), a highly diversified genus composed of so far 4 described species (Hahn et al., 2010; Kasalický et al., 2013; Kasalicky et al., 2010). Limnohabitans spp. are versatile in the incorporation of LMW substrates with a preference for simple organic acids and monosaccharides (Kasalický et al., 2013; Salcher et al., 2013) and typically show a quick response to nutrient enrichments (Pérez and Sommaruga, 2006; Peura et al., 2012b; Šimek et al., 2003). Moreover, these microbes seem to be tightly coupled to autochthonous carbon sources (Pérez and Sommaruga, 2006; Šimek et al., 2011b). In temperate lakes, Limnohabitans spp. have annually recurrent population maxima during phytoplankton blooms (Fig. 2; Eckert et al., 2012; Šimek et al., 2008), that are rapidly terminated by HNF due to preferential ingestion (Jezbera et al., 2006). However, the susceptibility to protistan grazing and viral lysis is species-specific (Šimek et al., 2010) and even closely related strains of Limnohabitans may differ in food quality for flagellates (Šimek et al., 2013).

Also some members of Alphaproteobacteria (esp. Sphingomonadaceae) and Gammaproteobacteria have a competitive and fast growing lifestyle as they can suddenly dominate microbial assemblages after nutrient en- richment and/or removal of grazers (Hutalle-Schmelzer et al., 2010; Newton and McMahon, 2011). While Sphingomonadaceae seem to profit from algal derived carbon sources (Dziallas and Grossart 2011; Neuenschwander et al., unpublished data), an enrichment of Gammaproteobacteria was only achieved at times of low phytoplankton biomass (Newton and McMahon, 2011; Peura et al., 2012b; Neuenschwander et al., unpublished data), indicating that their growth is induced by recycled or allochthonous DOM sources.

Flavobacteria and some populations of Sphingobacteria (Bacteroidetes) on the other hand are seen as typical bloom specialists favoured by phytoplankton bloom derived exudates or decay products (Newton and McMahon, 2011; Sarmento and Gasol, 2012). Member of this class can be enriched on algal exudates (Nelson and Carlson, 2012; Newton and McMahon, 2011), cultured on solid media (Cousin et al., 2008), and are abundant during phytoplankton blooms (Eckert et al., 2012; Eiler and Bertilsson, 2007; Salcher et al., 2010; Zeder et al., 2009). However, a consequent specialization seems likely, as even closely related populations of Flavobacteria showed striking seasonal patterns in enrichments during blooms of different algal species (Neuenschwander et al., unpublished data), pointing to specific adaptations to different types of algal exudates. Marine Flavobacteria were specialized in the degradation of algal derived polymers, which in turn were released as by-products in the form of simpler compounds (simple sugars, acetate, ammonia) that can then be exploited by other microbes such as Proteobacteria (Teeling et al., 2012; Williams et al., 2013). A similar ecological role of Flavobacteria can be expected in freshwaters.

\section{Physiologically specialized prokaryotes}

Some microbes fulfill a conspicuous role in aquatic environments by acting as key players in the nitrogen cycle (e.g., ammonia oxidizing Thaumarchaeota, denitrifying Epsilonproteobacteria), the sulfur cycle (e.g., sulfate reducing Deltaproteobacteria, sulfur oxidizing Epsilonproteobacteria), or the carbon cycle (e.g., methanotrophic Gammaproteobacteria, methylotrophic Betaproteobacteria) (Madigan, 2012). While most of these specialists are obligate or facultative anaerobes, ammonia oxidizing Thaumarchaeota and members of the methylotrophic LD28 tribe (Betaproteobacteria) dwell in oxygen saturated deep hypolimnia (Callieri et al., 2009; Salcher et al., 2008, 2011a; Urbach et al., 2001). LD28 Betaproteobacteria are closely related to the marine OM43 tribe of Methylophilaceae (Giovannoni et al., 2008; Halsey et al., 2011). They are methylotrophs, i.e., they use $\mathrm{C}_{1}$-compounds such as methanol as sources of carbon and/or energy gain. Decaying phytoplankton blooms and allochthonous DOM might be the main 
sources of methanol in freshwaters, as it is a degradation product of pectin and lignin (Halsey et al., 2011). Methylophilaceae were recently identified to be involved in the degradation of microcystins, toxins released by bloom forming cyanobacteria (Mou et al., 2013). Interestingly, LD28 Betaproteobacteria were repeatedly detected in deeper layers of lakes below the zone of primary producers, but were rare in the warm stratified water layers during summer (Salcher et al., 2008, 2011a). Moreover, distinct maxima were reported during mixis in autumnwinter (Fig. 2; Eiler et al., 2012), pointing to coldstenothermic adaptation and a beneficial effect of specific resources that get enriched during mixis.

Also Thaumarchaeota thrive mostly in hypolimnia of deep lakes and have close relatives in marine realms (Callieri et al., 2009; Urbach et al., 2001). These Archaea are involved in ammonia oxidation and dark $\mathrm{CO}_{2}$ fixation in the hypolimnia of deep lakes (Auguet et al., 2012; Callieri et al., 2014), similar to their marine counterparts (Könneke et al., 2005). However, further knowledge about, e.g., seasonality and mortality factors of these small prokaryotes is still scarce (Auguet et al., 2011).

\section{Photo(hetero)trophic bacteria}

Most aquatic prokaryotes can use light for carbon fixation or energy generation ranging from pure photoautotrophy to photoheterotrophy. Cyanobacteria carry out oxygenic photosynthesis comparable to eukaryotic algae but use different light harvesting complexes, and some are even able to fix atmospheric nitrogen (Oliver et al., 2012). Freshwater cyanobacteria are very diverse and their morphology ranges from small coccoid single cells (picocyanobacteria, e.g. Synechococcus sp.) (Callieri et al., 2013) to large multicellular filaments (e.g., Planktothrix sp., Anabaena sp.). They can form dense blooms, with some taxa being able to regulate their buoyancy by gas vacuoles or to produce toxins as grazing defense agents (Dokulil and Teubner, 2000; Posch et al., 2012). There are several excellent reviews and books about the ecology of cyanobacteria that I would like to draw the readers' attention to (Callieri et al., 2012; Callieri and Stockner, 2002; Dokulil and Teubner, 2000; Oliver et al., 2012; Whitton, 2012).

Photoheterotrophy on the other side is the ability to utilize DOM and harvest light energy for ATP production. Two types of photoheterotrophs thrive in oxygenated freshwaters, i.e., rhodopsin bearing bacteria (RBs) and bacteriochlorophyll containing aerobic anoxygenic phototrophs (AAPs). Rhodopsins (simple retinal-binding membrane proteins that act as light driven proton pumps) are widespread among freshwater and marine prokaryotes, including some of the most abundant taxa [e.g., ac1 Actinobacteria, LD12 Alphaproteobacteria, several Sphingo- and Flavobacteria (Atamna-Ismaeel et al.,
2008; Martinez-Garcia et al., 2012)]. Most likely, rhodopsins generate ATP to fuel membrane transporters in order to better survive in nutrient limited environments (Kirchman and Hanson, 2013). AAPs on the other side are not very abundant in lakes and restricted to some members of Alpha-, Beta-, and Gammaproteobacteria (Martinez-Garcia et al., 2012; Salka et al., 2008). However, as most AAPs are typical opportunists [e.g., several Limnohabitans spp. (Zeng et al., 2012)] with fast growth rates, bigger than average cell size, and high susceptibility to protistan predation, their contribution to microbial biomass and carbon flow are high (Mašín et al., 2008). Although AAPs gain more light energy than RBs, also the costs of the more complex bacteriochlorophyll based light harvesting machinery are substantially higher. Therefore, the low synthesizing costs and simplicity of rhodopsins might be the main reason for the success of RBs (Kirchman and Hanson, 2013).

\section{SPATIAL NICHES IN THE PELAGIAL OF LAKES}

Planktonic microorganisms show distinct spatial patterns that can range from micro-scale $(\mu \mathrm{m}-\mathrm{mm})$ to largescale (m-km) patchiness (Blackburn et al., 1998; Salcher et al., 2011a). Micro-scale heterogeneity of resources is a strong structuring factor for microorganisms, as dissolved and particulate organic matter in the water is present in small, ephemeral patches of e.g., algal exudates, material released by viral lysis, autolysis, or sloppy zooplankton feeding, detritus, or sinking lake snow particles (Blackburn et al., 1998; Stocker, 2012). Such micro-scale resource-rich patches in marine environments can be exploited by chemotactic motile bacteria (Taylor and Stocker, 2012), resulting in an accumulation of opportunistic bacteria (Barbara and Mitchell, 2003). Chemotaxis for inorganic nutrients (phosphorus, nitrate, and ammonium) of prominent freshwater bacterial populations has been demonstrated recently (Dennis et al., 2013). Besides micro-scale distribution of microbes, also large-scale longitudinal changes in nutrient regimes, temperature, and phytoplankton assemblages can act as niche separators for microorganisms. A changing importance from allochthonous DOM resulting in net heterotrophy in inflow regions towards a more phototrophic assemblage with pronounced shifts in microbial activity and assemblage composition has been reported for large reservoirs and lakes (Comerma et al., 2003; Reichart and Simon, 1996; Salcher et al., 2011a; Šimek et al., 2011a). The vertical structuring of the pelagial of stratified lakes is based on differences in temperature (epi-, meta-, and hypolimnion), light (euphotic and aphotic zone), and oxygen content (oxic and hypoxic zone; Wetzel, 2001). The vertical distribution of bacteria has been studied in detail, as oxygen gradients strongly influence organisms, thus, chemoclines and hypoxic hypolimnia provide niches for 
specialized microorganisms [e.g., sulphur oxidisers, fermenting or methanogenic bacteria (Madigan, 2012)]. Moreover, the well illuminated and - during summer stratification - warm surface water is inhabited by microorganisms that differ from those adapted to oxygenated hypolimnia due to several reasons. Firstly, temperature per se plays an important role, as total bacterial growth rates are tightly correlated to water temperature (Coveney and Wetzel, 1995; White et al., 1991). Secondly, many bacteria live phototrophic or photo-heterotrophic and are therefore dependent on light. Thirdly, phytoplankton exudates are main carbon sources for microbes (Giroldo et al., 2007; Hama and Handa, 1987) and some opportunistic taxa are well adapted to different epilimnetic phytoplankter (Eckert et al., 2012; Eiler and Bertilsson, 2004; Šimek et al., 2011b).

\section{A SYNOPTIC VIEW ON THE SEASONAL SUCCESSION OF FRESHWATER MICROBES IN TEMPERATE LAKES}

Temporal changes in the bacterioplankton are frequently referred to as another mode of niche separation besides spatial patchiness. Especially temperate lakes undergo strong seasonal changes in abiotic (e.g., temperature, light, oxygen) and biotic characteristics, and therefore, also microbes show a distinct seasonality with reoccurring patterns. These seasonal changes mostly take place in the epilimnion and are tightly linked to the main factors shaping microbial assemblages in the pelagial of lakes and ponds. Based on data from 2 contrasting prealpine lakes (small, shallow, oligomesotrophic Piburger See, Austria; and large, deep, mesotrophic Lake Zurich, Switzerland; Fig. 2) and other relevant literature, I will try to summarize the characteristic seasonal succession of microbial populations (Fig. 3), analogous to the wellknown PEG model for phyto- and zooplankton (Sommer et al., 1986, 2012).

Typically, temperature and DOC are the limiting factors for microbial growth during winter (Figs. 2, 3). As soon as water temperature and solar radiation reach a certain threshold and an algal spring bloom develops (Sommer et al., 2012), some fast growing opportunistic bacteria profit from phytoplankton derived DOM and grow to high densities (Eckert et al., 2012; Salcher et al., 2010; Zeder et al., 2009; Zwisler et al., 2003). Small transient populations of Flavobacteria might be responsible for polymer degradation (Teeling et al., 2012; Williams et al., 2013), while e.g., Limnohabitans spp. (Betaproteobacteria) might grow on algal derived monosaccharides (Kasalický et al., 2013; Salcher et al., 2013; Šimek et al., 2011b). Population maxima of such bloom specialists are usually only short-living due to depletion of resources (esp. phosphorus) and a rapid elimination by bacterivorous protists and viruses (Eckert et al., 2012). Subsequently, grazing resistant defense specialists with lower growth rates such as ac1 Actinobacteria and filamentous bacteria rise in abundance (Allgaier and Grossart, 2006; Eckert et al., 2012; Salcher et al., 2010). These microbes might also directly profit from algal derived DOM or from recycled carbon released during flagellate grazing or viral lysis (Eckert et al., 2013; Salcher et al., 2013). During the clear-water phase, filaments are eliminated by filter feeding daphnids (Langenheder and Jürgens, 2001; Pernthaler et al., 2004; Schauer et al., 2006), while small ac1 Actinobacteria might suffer from viral lysis or bottom-up limitation (Šimek et al., 2006). LD12 Alphaproteobacteria thrive in such nutrient depleted situations and might moreover profit from increasing water temperatures and solar radiation (Eiler et al., 2012; Salcher et al., 2011b). In case of additional phytoplankton blooms during summer, these oligotrophic ultramicrobacteria get displaced by opportunistically growing microbes with another succession starting comparable to the one after spring blooms (Figs. $2,3)$. However, as phosphorus is limiting in summer, population maxima might not be as pronounced as in spring. In late summer to autumn, also nitrogen sources get depleted, consecutively favouring oligotrophic ultramicrobacteria such as LD12 Alphaproteobacteria (Heinrich et al., 2013; Salcher et al., 2011b). At the onset of autumnal mixis, microbial populations get passively entrained in deeper water layers where suboptimal conditions prevail. Simultaneously, decreasing water temperatures and enhanced resource availability due to mixis might favour specialized populations such as LD28 Betaproteobacteria (Fig. 2; Salcher et al., 2008).

The synoptic view on the seasonal succession of different bacterioplankton populations presented here, however, is definitely not complete, as most microbes so far lack cultured representatives and a correct assignment of their ecological role. Future work focusing on the isolation of some of the most abundant freshwater microbes (e.g., ac1 Actinobacteria, LD12 Alphaproteobacteria) is needed to gain more information on their life-style, growth dynamics, and specific physiological adaptations (Giovannoni and Stingl, 2007). This, together with single-cell analyses such as MAR-FISH (Salcher et al., 2013) or single amplified genomes (Blainey, 2013) and meta-omics approaches (Simon and Daniel, 2011) may further elucidate ecological functions of the dominant microbes and identify their driving forces, and thus, shed light on the reasons for their apparent success in freshwaters. However, the so far recognized recurrent spatio-temporal distribution patterns together with several ecophysiological properties already point to pronounced ecological niche separation of the dominant microbial populations, and thus, might be a reason for the high diversity, analogous to the paradox of the plankton for algae (Hutchinson, 1961). 


\section{ACKNOWLEDGEMENTS}

I would like to thank T. Posch, J. Pernthaler, E.M. Eckert, and S.M. Neuenschwander for discussion, helpful suggestions on earlier versions of this manuscript, and long-lasting support. Further I am grateful for the valuable comments of two anonymous reviewers. Financial support was provided by the Swiss National Science Foundation (SNF, Project 31003A-117765) and, as part of the European Science Foundation EUROCORES Program EuroEEFG, by the SNF Project 31EE30-132771.

\section{REFERENCES}

Allgaier M, Grossart H, 2006. Diversity and seasonal dynamics of Actinobacteria populations in four lakes in northeastern Germany. Appl. Environ. Microbiol. 72:3489-3497.

Andersson A, Larsson U, Hagström A, 1986. Size-selective grazing by a microflagellate on pelagic bacteria. Mar. Ecol. 33:51-57.

Atamna-Ismaeel N, Sabehi G, Sharon I, Witzel KP, Labrenz M, Jurgens K, Barkay T, Stomp M, Huisman J, Beja O, 2008. Widespread distribution of proteorhodopsins in freshwater and brackish ecosystems. ISME J. 2:656-662.

Auguet JC, Nomokonova N, Camarero L, Casamayor EO, 2011. Seasonal changes of freshwater ammonia-oxidizing archaeal assemblages and nitrogen species in oligotrophic alpine lakes. Appl. Environ. Microbiol. 77:1937-1945.

Auguet JC, Triado-Margarit X, Nomokonova N, Camarero L, Casamayor EO, 2012. Vertical segregation and phylogenetic characterization of ammonia-oxidizing Archaea in a deep oligotrophic lake. ISME J. 6:1786-1797.

Azam F, Fenchel T, Field J, Gray J, Meyer-Reil L, Thingstad T, 1983. The ecological role of water-column microbes in the sea. Mar. Ecol. Prog. Ser. 10:257-263.

Bahr M, Hobbie JE, Sogin ML, 1996. Bacterial diversity in an arctic lake: A freshwater SAR11 cluster. Aquat. Microb. Ecol. 11:271-277.

Barbara GM, Mitchell JG, 2003. Marine bacterial organisation around point-like sources of amino acids. FEMS Microbiol. Ecol. 43:99-109.

Beier S, Bertilsson S, 2011. Uncoupling of chitinase activity and uptake of hydrolysis products in freshwater bacterioplankton. Limnol. Oceanogr. 56:1179-1188.

Berggren M, Laudon H, Haei M, Strom L, Jansson M, 2010. Efficient aquatic bacterial metabolism of dissolved low-molecular-weight compounds from terrestrial sources. ISME J. 4:408-416.

Bertilsson S, Tranvik LJ, 1998. Photochemically produced carboxylic acids as substrates for freshwater bacterioplankton. Limnol. Oceanogr. 43:885-895.

Blackburn N, Fenchel T, Mitchell J, 1998. Microscale nutrient patches in planktonic habitats shown by chemotactic bacteria. Science 282:2254-2256.

Blainey PC, 2013. The future is now: Single-cell genomics of bacteria and archaea. FEMS Microbiol. Rev. 37:407-427.

Buck U, Grossart HP, Amann R, Pernthaler J, 2009. Substrate incorporation patterns of bacterioplankton populations in stratified and mixed waters of a humic lake. Environ. Microbiol. 11:1854-1865.
Burkert U, Warnecke F, Babenzien D, Zwirnmann E, Pernthaler J, 2003. Members of a readily enriched beta-proteobacterial clade are common in surface waters of a humic lake. Appl. Environ. Microbiol. 69:6550-6559.

Callieri C, Stockner JG, 2002. Freshwater autotrophic picoplankton: a review. J. Limnol. 61:1-14.

Callieri C, Corno G, Caravati E, Galafassi S, Bottinell M, Bertoni R, 2007. Photosynthetic characteristics and diversity of freshwater Synechococcus at two depths during different mixing conditions in a deep oligotrophic lake. J. Limnol. 66:81-89.

Callieri C, Corno G, Caravati E, Rasconi S, Contesini M, Bertoni R, 2009. Bacteria, Archaea, and Crenarchaeota in the epilimnion and hypolimnion of a deep holo-oligomictic lake. Appl. Environ. Microbiol. 75:7298-7300.

Callieri C, Cronberg G, Stockner J, 2012. Freshwater picocyanobacteria: Single cells, microcolonies and colonial forms, p. 229-269. In: B.A. Whitton (ed.), Ecology of Cyanobacteria II. Springer Netherlands.

Callieri C, Coci M, Corno G, Macek M, Modenutti B, Balseiro E, Bertoni R, 2013. Phylogenetic diversity of nonmarine picocyanobacteria. FEMS Microbiol. Ecol. 85:293-301.

Callieri C, Coci M, Eckert EM, Salcher MM, Bertoni R, 2014. Archaea and Bacteria in deep lake hypolimnion: in situ dark inorganic carbon uptake. J. Limnol. 73:47-54.

Cardinale BJ, 2011. Biodiversity improves water quality through niche partitioning. Nature 472:86-89.

Chrzanowski T, Šimek K, 1990. Prey-size selection by freshwater flagellated protozoa. Limnol. Oceanogr. 35:1429-1436.

Comerma A, Garcia JC, Romero M, Armengol J, Šimek K, 2003. Carbon flow dynamics in the pelagic community of the Sau Reservoir (Catalonia, NE Spain). Hydrobiologia 504:87-98.

Corno G, Jürgens K, 2006. Direct and indirect effects of protist predation on population size structure of a bacterial strain with high phenotypic plasticity. Appl. Environ. Microbiol. 72:78-86.

Corno G, Caravati E, Callieri C, Bertoni R, 2008. Effects of predation pressure on bacterial abundance, diversity, and sizestructure distribution in an oligotrophic system. J. Limnol. 67:107-119.

Cousin S, Brambilla E, Yang J, Stackebrandt E, 2008. Culturable aerobic bacteria from the upstream region of a karst water rivulet. Internat. Microbiol. 11:91-100.

Coveney M, Wetzel R, 1995. Biomass, production, and specific growth rate of bacterioplankton and coupling to phytoplankton in an oligotrophic lake. Limnol. Oceanogr. 40:1187-1200.

Dennis PG, Seymour J, Kumbun K, Tyson GW, 2013. Diverse populations of lake water bacteria exhibit chemotaxis towards inorganic nutrients. ISME J. 7:1661-1664.

Dokulil M, Teubner K, 2000. Cyanobacterial dominance in lakes. Hydrobiologia 438:1-12.

Dziallas C, Grossart H-P, 2011. Temperature and biotic factors influence bacterial communities associated with the cyanobacterium Microcystis sp. Environ. Microbiol. 13: 1632-1641.

Eckert EM, Salcher MM, Posch T, Eugster B, Pernthaler J, 2012. Rapid successions affect microbial N-acetyl-glucosamine uptake patterns during a lacustrine spring phytoplankton bloom. Environ. Microbiol. 14:794-806. 
Eckert EM, Baumgartner M, Huber IM, Pernthaler J, 2013. Grazing resistant freshwater bacteria profit from chitin and cell-wall derived organic carbon. Environ. Microbiol. 15:2019-2030.

Eiler A, Bertilsson S, 2004. Comparison of freshwater bacterial communities associated with cyanobacterial blooms in four swedish lakes. Environ. Microbiol. 6:1228-1243.

Eiler A, Bertilsson S, 2007. Flavobacteria blooms in four eutrophic lakes: Linking population dynamics of freshwater bacterioplankton to resource availability. Appl. Environ. Microbiol. 73:3511-3518.

Eiler A, Heinrich F, Bertilsson S, 2012. Coherent dynamics and association networks among lake bacterioplankton taxa. ISME J. 6:330-342.

Farrelly V, Rainey F, Stackebrandt E, 1995. Effect of genome size and rrn gene copy number on PCR amplification of 16S rRNA genes from a mixture of bacterial species. Appl. Environ. Microbiol. 61:2798-2801.

Frostegard A, Courtois S, Ramisse V, Clerc S, Bernillon D, Le G, Jeannin FP, Nesme X, Simonet P, 1999. Quantification of bias related to the extraction of DNA directly from soils. Appl. Environ. Microbiol. 65:5409-5420.

Garcia SL, McMahon KD, Martinez-Garcia M, Srivastava A, Sczyrba A, Stepanauskas R, Grossart H-P, Woyke T, Warnecke F, 2013. Metabolic potential of a single cell belonging to one of the most abundant lineages in freshwater bacterioplankton. ISME J. 7:137-147.

Giovannoni S, Stingl U, 2007. The importance of culturing bacterioplankton in the 'omics' age. Nat. Rev. Microbiol. 5:820-826.

Giovannoni SJ, Bibbs L, Cho JC, Stapels MD, Desiderio R, Vergin KL, Rappe MS, Laney S, Wilhelm LJ, Tripp HJ, Mathur EJ, Barofsky DF, 2005a. Proteorhodopsin in the ubiquitous marine bacterium SAR11. Nature 438:82-85.

Giovannoni SJ, Tripp HJ, Givan S, Podar M, Vergin KL, Baptista D, Bibbs L, Eads J, Richardson TH, Noordewier M, Rappe MS, Short JM, Carrington JC, Mathur EJ, 2005b. Genome streamlining in a cosmopolitan oceanic bacterium. Science 309:1242-1245.

Giovannoni SJ, Hayakawa DH, Tripp HJ, Stingl U, Givan SA, Cho JC, Oh HM, Kitner JB, Vergin KL, Rappe MS, 2008. The small genome of an abundant coastal ocean methylotroph. Environ. Microbiol. 10:1771-1782.

Giroldo D, Vieira AAH, 2005. Polymeric and free sugars released by three phytoplanktonic species from a freshwater tropical eutrophic reservoir. J. Plankton Res. 27:695-705.

Giroldo D, Ortolano PIC, Vieira AAH, 2007. Bacteria-algae association in batch cultures of phytoplankton from a tropical reservoir: the significance of algal carbohydrates. Freshwater Biol. 52:1281-1289.

Glöckner FO, Zaichikov E, Belkova N, Denissova L, Pernthaler J, Pernthaler A, Amann R, 2000. Comparative 16S rRNA analysis of lake bacterioplankton reveals globally distributed phylogenetic clusters including an abundant group of Actinobacteria. Appl. Environ. Microbiol. 66:5053-5065.

Gómez P, Buckling A, 2013. Real-time microbial adaptive diversification in soil. Ecol. Lett. 16:650-655.

Grossart HP, 2010. Ecological consequences of bacterioplankton lifestyles: changes in concepts are needed. Environ. Microbiol. Rep. 2:706-714.
Grossart HP, Jezbera J, Horňák K, Hutalle KML, Buck U, Šimek $\mathrm{K}, 2008$. Top-down and bottom-up induced shifts in bacterial abundance, production and community composition in an experimentally divided humic lake. Environ. Microbiol. 10:635-652.

Hahn M, 2003. Isolation of strains belonging to the cosmopolitan Polynucleobacter necessarius cluster from freshwater habitats located in three climatic zones. Appl. Environ. Microbiol. 69:5248-5254.

Hahn M, 2006. The microbial diversity of inland waters. Curr. Opin. Microbiol. 17:256-261.

Hahn M, Höfle M, 1998. Grazing pressure by a bacterivorous flagellate reverses the relative abundance of Comamonas acidivorans PX54 and Vibrio strain CB5 in chemostat coculture. Appl. Environ. Microbiol. 64:1910-1918.

Hahn M, Höfle M, 2001. Grazing of protozoa and its effect on populations of aquatic bacteria. FEMS Microbiol. Ecol. 35:113-121.

Hahn M, Moore E, Höfle M, 1999. Bacterial filament formation, a defense mechanism against flagellate grazing, is growth rate controlled in bacteria of different phyla. Appl. Environ. Microbiol. 65:25-35.

Hahn MW, Schauer M, 2007. 'Candidatus Aquirestis calciphila' and 'Candidatus Haliscomenobacter calcifugiens', filamentous, planktonic bacteria inhabiting natural lakes. Int. J. Syst. Evol. Microbiol. 57:936-940.

Hahn MW, Lang E, Brandt U, Wu QL, Scheuerl T, 2009. Emended description of the genus Polynucleobacter and the species Polynucleobacter necessarius and proposal of two subspecies, $P$. necessarius subsp. necessarius subsp. nov. and $P$. necessarius subsp. asymbioticus subsp. nov. Int. J. Syst. Evol. Microbiol. 59:2002-2009.

Hahn MW, Kasalicky V, Jezbera J, Brandt U, Jezberova J, Šimek K, 2010. Limnohabitans curvus gen. nov., sp. nov., a planktonic bacterium isolated from a freshwater lake. Int. J. Syst. Evol. Microbiol. 60:1358-1365.

Hahn MW, Scheuerl T, Jezberova J, Koll U, Jezbera J, Šimek K, Vannini C, Petroni G, Wu QL, 2012. The passive yet successful way of planktonic life: Genomic and experimental analysis of the ecology of a free-living Polynucleobacter population. PLoS ONE 7:e32772.

Halsey KH, Carter AE, Giovannoni SJ, 2011. Synergistic metabolism of a broad range of $\mathrm{C}_{1}$ compounds in the marine methylotrophic bacterium HTCC2181. Environ. Microbiol. 14:630-640.

Hama T, Handa N, 1987. Pattern of organic-matter production by natural phytoplankton population in a eutrophic lake. 2 . Extracellular products. Arch. Hydrobiol. 109:227-243.

Heinrich F, Eiler A, Bertilsson S, 2013. Seasonality and environmental control of freshwater SAR11 (LD12) in a temperate lake (Lake Erken, Sweden). Aquat. Microb. Ecol. 70:33-44.

Herlemann DPR, Labrenz M, Jürgens K, Bertilsson S, Waniek JJ, Andersson AF, 2011. Transitions in bacterial communities along the $2000 \mathrm{~km}$ salinity gradient of the Baltic Sea. ISME J. 5:1571-1579.

Hutalle-Schmelzer KML, Zwirnmann E, Krüger A, Grossart HP, 2010. Enrichment and cultivation of pelagic bacteria from a humic lake using phenol and humic matter additions. FEMS Microbiol. Ecol. 72:58-73. 
Hutchinson GE, 1961. The paradox of the plankton. Am. Nat. 95:137-145.

Jezbera J, Horňák K, Šimek K, 2006. Prey selectivity of bacterivorous protists in different size fractions of reservoir water amended with nutrients. Environ. Microbiol. 8:1330-1339.

Jezbera J, Sharma AK, Brandt U, Doolittle WF, Hahn MW, 2009. 'Candidatus Planktophila limnetica', an actinobacterium representing one of the most numerically important taxa in freshwater bacterioplankton. Int. J. Syst. Evol. Microbiol. 59:2864-2869.

Jezbera J, Jezberová J, Brandt U, Hahn MW, 2011. Ubiquity of Polynucleobacter necessarius subspecies asymbioticus results from ecological diversification. Environ. Microbiol. 13:922-931.

Jezbera J, Jezberová J, Kasalický V, Šimek K, Hahn MW, 2013. Patterns of Limnohabitans microdiversity across a large set of freshwater habitats as revealed by reverse line blot hybridization. PLoS ONE 8:e58527.

Jones SE, Lennon JT, 2010. Dormancy contributes to the maintenance of microbial diversity. Proc. Natl. Acad. Sci. USA 107:5881-5886.

Jürgens K, Matz C, 2002. Predation as a shaping force for the phenotypic and genotypic composition of planktonic bacteria. Anton. Leeuw. Int. J. G. 81:413-434.

Jürgens K, Stolpe G, 1995. Seasonal dynamics of crustacean zooplankton, heterotrophic nanoflagellates and bacteria in a shallow, eutrophic lake. Freshwater Biol. 33:27-38.

Kasalicky V, Jezbera J, Šimek K, Hahn MW, 2010. Limnohabitans planktonicus sp. nov., and Limnohabitans parvus sp. nov., two novel planktonic Betaproteobacteria isolated from a freshwater reservoir and emended description of the genus Limnohabitans. Int. J. Syst. Evol. Microbiol. 60:2710-2714.

Kasalický V, Jezbera J, Hahn MW, Šimek K, 2013. The diversity of the Limnohabitans genus, an important group of freshwater bacterioplankton, by characterization of 35 isolated strains. PLoS ONE 8:e58209.

Kirchman DL, Hanson TE, 2013. Bioenergetics of photoheterotrophic bacteria in the oceans. Environ. Microbiol. Rep. 5:188-199.

Könneke M, Bernhard AE, de la Torre JA, Walker CB, Waterbury JB, Stahl DA, 2005. Isolation of an autotrophic ammonia-oxidizing marine archaeon. Nature 437:543-546.

Kritzberg ES, Cole JJ, Pace ML, Granéli W, Bade DL, 2004. Autochthonous versus allochthonous carbon sources of bacteria: Results from whole-lake ${ }^{13} \mathrm{C}$ addition experiments. Limnol. Oceanogr. 49:588-596.

Lampert W, 2006. Daphnia: Model herbivore, predator and prey Pol. J. Ecol. 54:607-620.

Langenheder S, Jürgens K, 2001. Regulation of bacterial biomass and community structure by metazoan and protozoan predation. Limnol. Oceanogr. 46:121-134.

Lawrence D, Fiegna F, Behrends V, Bundy JG, Phillimore AB, Bell TB, Barraclough TG, 2012. Species interactions alter evolutionary responses to a novel environment. PLoS Biol. 10:e1001330.

Lennon JT, Jones SE, 2011. Microbial seed banks: the ecological and evolutionary implications of dormancy. Nat .Rev. Micro. 9:119-130.

Logares R, Brate J, Heinrich F, Shalchian-Tabrizi K, Bertilsson $\mathrm{S}, 2010$. Infrequent transitions between saline and fresh waters in one of the most abundant microbial lineages (SAR11). Mol. Biol. Evol. 27:347-357.
Madigan MT, 2012. Brock biology of microorganisms, $13^{\text {th }}$ ed. Benjamin Cummings: 1152 pp.

Martinez-Garcia M, Swan BK, Poulton NJ, Gomez ML, Masland D, Sieracki ME, Stepanauskas RE, 2012. High-throughput single-cell sequencing identifies photoheterotrophs and chemoautotrophs in freshwater bacterioplankton. ISME J. 6:113-123.

Mašín M, Nedoma J, Pechar L, Koblížek M, 2008. Distribution of aerobic anoxygenic phototrophs in temperate freshwater systems. Environ. Microbiol. 10:1988-1996.

Meon B, Jüttner F, 1999. Concentrations and dynamics of free mono- and oligosaccharides in a shallow eutrophic lake measured by thermospray mass spectrometry. Aquat. Microb. Ecol. 16:281-293.

Morris RM, Rappe MS, Connon SA, Vergin KL, Siebold WA, Carlson CA, Giovannoni SJ, 2002. SAR11 clade dominates ocean surface bacterioplankton communities. Nature 420:806-810.

Mou X, Lu X, Jacob J, Sun S, Heath R, 2013. Metagenomic identification of bacterioplankton taxa and pathways involved in microcystin degradation in Lake Erie. PLoS ONE 8:e61890.

Nelson CE, Carlson CA, 2012. Tracking differential incorporation of dissolved organic carbon types among diverse lineages of Sargasso Sea bacterioplankton. Environ. Microbiol. 14:1500-1516.

Newton RJ, Jones SE, Eiler A, McMahon KD, Bertilsson S, 2011. A guide to the natural history of freshwater lake bacteria. Microbiol. Mol. Biol. R. 75:14-49.

Newton RJ, Jones SE, Helmus MR, McMahon KD, 2007. Phylogenetic ecology of the freshwater Actinobacteria acI lineage. Appl. Environ. Microbiol. 73:7169-7176.

Newton RJ, McMahon KD, 2011. Seasonal differences in bacterial community composition following nutrient additions in a eutrophic lake. Environ. Microbiol. 13:887-899.

Okazaki Y, Hodoki Y, Nakano SI, 2013. Seasonal dominance of CL500-11 bacterioplankton (Phylum Chloroflexi) in the oxygenated hypolimnion of Lake Biwa, Japan. FEMS Microbiol. Ecol. 83:82-92.

Oliver R, Hamilton D, Brookes J, Ganf G, 2012. Physiology, blooms and prediction of planktonic Cyanobacteria, p. 155194. In B.A. Whitton [ed.], Ecology of Cyanobacteria II. Springer Netherlands.

Pedrós-Alió C, 2012. The rare bacterial biosphere. Ann. Rev. Mar. Sci. 4:449-466.

Pérez MT, Sommaruga R, 2006. Differential effect of algal- and soil-derived dissolved organic matter on alpine lake bacterial community composition and activity. Limnol. Oceanogr. 51:2527-2537.

Pernthaler J, 2005. Predation on prokaryotes in the water column and its ecological implications. Nat. Rev. Microbiol. 3:537-546.

Pernthaler J, Glockner FO, Unterholzner S, Alfreider A, Psenner R, Amann R, 1998. Seasonal community and population dynamics of pelagic bacteria and archaea in a high mountain lake. Appl. Environ. Microbiol. 64:4299-4306.

Pernthaler J, Posch T, 2009. Microbial food webs, p. 244-251. In: G.E. Likens (ed.), Encyclopedia of inland waters. Elsevier.

Pernthaler J, Posch T, Šimek K, Vrba J, Pernthaler A, Glockner FO, Nubel U, Psenner R, Amann R, 2001. Predator-specific enrichment of Actinobacteria from a cosmopolitan freshwater clade in mixed continuous culture. Appl. Environ. Microbiol. 67:2145-2155. 
Pernthaler J, Zollner E, Warnecke F, Jurgens K, 2004. Bloom of filamentous bacteria in a mesotrophic lake: Identity and potential controlling mechanism. Appl. Environ. Microbiol. 70:6272-6281.

Personnic S, Domaizon I, Sime-Ngando T, Jacquet S, 2009. Seasonal variations of microbial abundances and virus- versus flagellate-induced mortality of picoplankton in three perialpine lakes. J. Plankton Res. 31:1161-1177.

Peura S, Eiler A, Bertilsson S, Nykanen H, Tiirola M, Jones RI, 2012a. Distinct and diverse anaerobic bacterial communities in boreal lakes dominated by candidate division OD1. ISME J. 6:1640-1652.

Peura S, Eiler A, Hiltunen M, Nykänen H, Tiirola M, Jones RI, 2012 b. Bacterial and phytoplankton responses to nutrient amendments in a boreal lake differ according to season and to taxonomic resolution. PLoS ONE 7:e38552.

Piwosz K, Salcher MM, Zeder M, Ameryk A, Pernthaler J, 2013. Seasonal dynamics and activity of typical freshwater bacteria in brackish waters of the Gulf of Gdansk. Limnol. Oceanogr. 58:817-826.

Pomeroy LR, 1974. Oceans food web, a changing paradigm. Bioscience 24:499-504.

Posch T, Franzoi J, Prader M, Salcher MM, 2009. New image analysis tool to study biomass and morphotypes of three major bacterioplankton groups in an alpine lake. Aquat. Microb. Ecol. 54:113-126.

Posch T, Šimek K, Vrba J, Pernthaler J, Nedoma J, Sattler B, Sonntag B, Psenner R, 1999. Predator-induced changes of bacterial size-structure and productivity studied on an experimental microbial community. Aquat. Microb. Ecol. 18:235-246.

Posch T, Jezbera J, Vrba J, Šimek K, Pernthaler J, Andreatta S, Sonntag B, 2001. Size selective feeding in Cyclidium glaucoma (Ciliophora, Scuticociliatida) and its effects on bacterial community structure: a study from a continuous cultivation system. Microb. Ecol. 42:217-227.

Posch T, Koster O, Salcher MM, Pernthaler J, 2012. Harmful filamentous cyanobacteria favoured by reduced water turnover with lake warming. Nature Clim. Change 2:809-813.

Pradeep Ram AS, Nishimura Y,Tomaru Y, Nagasaki K, Nagata $\mathrm{T}, 2010$. Seasonal variation in viral-induced mortality of bacterioplankton in the water column of a large mesotrophic lake (Lake Biwa, Japan). Aquat. Microb. Ecol. 58:249-259.

Rainey PB, Travisano M, 1998. Adaptive radiation in a heterogeneous environment. Nature 394:69-72.

Rainey PB, Buckling A, Kassen R, Travisano M, 2000. The emergence and maintenance of diversity: Insights from experimental bacterial populations. Trends Ecol. Evol. 15:243-247.

Reichart I, Simon M, 1996. Horizontal variability of bacterioplankton growth dynamics in a large lake. Aquat. Microb. Ecol. 11:31-41.

Rosenstock B, Simon M, 1993. Use of dissolved combined and free amino-acids by planktonic bacteria in Lake Constance. Limnol. Oceanogr. 38:1521-1531.

Salcher MM, Hofer J, Horňák K, Jezbera J, Sonntag B, Vrba J, Šimek K, Posch T, 2007. Modulation of microbial predatorprey dynamics by phosphorus availability: growth patterns and survival strategies of bacterial phylogenetic clades. FEMS Microbiol. Ecol. 60:40-50.

Salcher MM, Pernthaler J, Frater N, Posch T, 2011a. Vertical and longitudinal distribution patterns of differnt bacterio- plankton populations in a canyon-shaped, deep prealpine lake. Limnol. Oceanogr. 56:2027-2039.

Salcher MM, Pernthaler J, Posch T, 2010. Spatiotemporal distribution and activity patterns of bacteria from three phylogenetic groups in an oligomesotrophic lake. Limnol. Oceanogr. 55:846-856.

Salcher MM, Pernthaler J, Posch T, 2011b. Seasonal bloom dynamics and ecophysiology of the freshwater sister clade of SAR11 bacteria 'that rule the waves' (LD12). ISME J. 5:1242-1252.

Salcher MM, Pernthaler J, Zeder M, Psenner R, Posch T, 2008. Spatio-temporal niche separation of planktonic Betaproteobacteria in an oligo-mesotrophic lake. Environ. Microbiol. 10:2074-2086.

Salcher MM, Posch T, Pernthaler J, 2013. In situ substrate preferences of abundant bacterioplankton populations in a prealpine freshwater lake. ISME J. 7:896-907.

Salka I, Moulisova V, Koblizek M, Jost G, Jurgens K, Labrenz M, 2008. Abundance, depth distribution, and composition of aerobic bacteriochlorophyll a-producing bacteria in four basins of the central Baltic Sea. Appl. Environ. Microbiol. 74:4398-4404.

Sanders R, Porter K, Bennett S, DeBiase A, 1989. Seasonal patterns of bacterivory by flagellates, ciliates, rotifers, and cladocerans in a freshwater planktonic community. Limnol. Oceanogr. 34:673-687.

Sarmento H, Gasol JM, 2012. Use of phytoplankton-derived dissolved organic carbon by different types of bacterioplankton. Environ. Microbiol. 14:2348-2360.

Schauer M, Hahn M, 2005. Diversity and phylogenetic affiliations of morphologically conspicuous large filamentous bacteria occurring in the pelagic zones of a broad spectrum of freshwater habitats. Appl. Environ. Microbiol. 71:1931-1940.

Schauer M, Jiang J, Hahn M, 2006. Recurrent seasonal variations in abundance and composition of filamentous SOL cluster bacteria (Saprospiraceae, Bacteroidetes) in oligomesotrophic Lake Mondsee (Austria). Appl. Environ. Microbiol. 72:4704-4712.

Sharma AK, Sommerfeld K, Bullerjahn GS, Matteson AR, Wilhelm SW, Jezber J, Brandt U, Doolittle WF, Hahn MW, 2009. Actinorhodopsin genes discovered in diverse freshwater habitats and among cultivated freshwater Actinobacteria. ISME J. 3:726-737.

Sherr E, Sherr B, 1988. Role of microbes in pelagic food webs - a revised concept. Limnol. Oceanogr. 33:1225-1227.

Šimek K, Comerma M, Garcia JC, Nedoma J, Marce R, Armengol J, 2011a. The effect of river water circulation on the distribution and functioning of reservoir microbial communities as determined by a relative distance approach. Ecosystems 14:1-14.

Šimek K, Horňák K, Jezbera J, Masin M, Nedoma J, Gasol J, Schauer M, 2005. Influence of top-down and bottom-up manipulation on the R-BT065 subcluster of beta-proteobacteria, an abundant group in bacterioplankton of a freshwater reservoir. Appl. Environ. Microbiol. 71:2381-2390.

Šimek K, Horňák K, Jezbera J, Nedoma J,Vrba J, Straskrabová V, Macek M, Dolan J, Hahn M, 2006. Maximum growth rates and possible life strategies of different bacterioplankton groups in relation to phosphorus availability in a freshwater reservoir. Environ. Microbiol. 8:1613-1624.

Šimek K, Horňák K, Jezbera J, Nedoma J, Znachor P, Hejzlar J, Sed'a J, 2008. Spatio-temporal patterns of bacterioplankton production and community composition related to phyto- 
plankton composition and protistan bacterivory in a dam reservoir. Aquat. Microb. Ecol. 51:249-262.

Šimek K, Horňák K, Masin M, Christaki U, Nedoma J, Weinbauer M, Dolan J, 2003. Comparing the effects of resource enrichment and grazing on a bacterioplankton community of a meso-eutrophic reservoir. Aquat. Microb. Ecol. 31:123-135.

Šimek K, Kasalicky V, Horňák K, Hahn MW, Weinbauer MG, 2010. Assessing niche separation among coexisting Limnohabitans strains through interactions with a competitor, viruses, and a bacterivore. Appl. Environ. Microbiol. 76:1406-1416.

Šimek K, Kasalicky V, Jezbera J, Horňák K, Nedoma J, Hahn MW, Bass D, Jost S, Boenigk J, 2013. Differential freshwater flagellate community response to bacterial food quality with a focus on Limnohabitans bacteria. ISME J. 7:1519-1530.

Šimek K, Kasalicky V, Zapomelova E, Horňák K, 2011b. Algaderived substrates select for distinct betaproteobacterial lineages and contribute to niche separation in Limnohabitans strains. Appl. Environ. Microbiol. 77:7307-7315.

Šimek K, Pernthaler J, Weinbauer MG, Horňák K, Dolan J, Nedoma J, Masin M, Amann R, 2001. Changes in bacterial community composition and dynamics and viral mortality rates associated with enhanced flagellate grazing in a mesoeutrophic reservoir. Appl. Environ. Microbiol. 67:2723-2733.

Šimek K, Weinbauer M, Horňák K, Jezbera J, Nedoma J, Dolan J, 2007. Grazer and virus-induced mortality of bacterioplankton accelerates development of Flectobacillus populations in a freshwater community. Environ. Microbiol. 9:789-800.

Simon C, Daniel R, 2011. Metagenomic analyses: Past and future trends. Appl. Environ. Microbiol. 77:1153-1161.

Sommer U, Gliwicz M, Lampert E, Duncan A, 1986. The PEGmodel of seasonal succession of planktonic events in fresh waters. Arch. Hydrobiol. 106:433-471.

Sommer U, Adrian R, De Senerpont Domis L, Elser JJ, Gaedke U, Ibelings B, Jeppesen E, Lürling M, Molinero JC, Mooij WM, van Donk E, Winder M, 2012. Beyond the Plankton Ecology Group (PEG) model: Mechanisms driving plankton succession. Ann. Rev. Ecol. Syst. 43:429-448.

Stocker R, 2012. Marine microbes see a sea of gradients. Science 338:628-633.

Sundh I, 1992. Biochemical composition of dissolved organic carbon derived from phytoplankton and used by heterotrophic bacteria. Appl. Environ. Microbiol. 58:2938-2947.

Tarao M, Jezbera J, Hahn MW, 2009. Involvement of cell surface structures in size-independent grazing resistance of freshwater Actinobacteria. Appl. Environ. Microbiol. 75:4720-4726.

Taylor JR, Stocker R, 2012. Trade-offs of chemotactic foraging in turbulent water. Science 338:675-679.

Teeling H, Fuchs BM, Becher D, Klockow C, Gardebrecht A, Bennke CM, Kassabgy M, Huang S, Mann AJ, Waldmann J, Weber M, Klindworth A, Otto A, Lange J, Bernhardt J, Reinsch C, Hecker M, Peplies J, Bockelmann FD, Callies U, Gerdts G, Wichels A, Wiltshire KH, Glöckner FO, Schweder T, Amann R, 2012. Substrate-controlled succession of marine bacterioplankton populations induced by a phytoplankton bloom. Science 336:608-611.

Thingstad TF, Lignell R, 1997. Theoretical models for the control of bacterial growth rate, abundance, diversity and carbon demand. Aquat. Microb. Ecol. 13:19-27.

Thingstad TF, Øvreås L, Egge JK, Løvdal T, Heldal M, 2005. Use of non-limiting substrates to increase size; a generic strategy to simultaneously optimize uptake and minimize predation in pelagic osmotrophs? Ecol. Lett. 8:675-682.

Thomas R, Berdjeb L, Sime-Ngando T, Jacquet S, 2011. Viral abundance, production, decay rates and life strategies (lysogeny versus lysis) in Lake Bourget (France). Environ. Microbiol. 13:616-630.

Turner PE, Souza V, Lenski RE, 1996. Tests of ecological mechanisms promoting the stable coexistence of two bacterial genotypes. Ecology 77:2119-2129.

Urbach E, Vergin K, Young L, Morse A, Larson G, Giovannoni S, 2001. Unusual bacterioplankton community structure in ultraoligotrophic Crater lake. Limnol. Oceanogr. 46:557-572.

Warnecke F, Sommaruga R, Sekar R, Hofer JS, Pernthaler J, 2005. Abundances, identity, and growth state of Actinobacteria in mountain lakes of different UV transparency. Appl. Environ. Microbiol. 71:5551-5559.

Weinbauer MG, 2004. Ecology of prokaryotic viruses. FEMS Microbiol. Rev. 28:127-181.

Wetzel R, 2001. Limnology. Lake and river ecosystems, $3^{\text {rd }}$ ed. Academic Press: 1006 pp.

White PA, Kalff J, Rasmussen JB, Gasol JM, 1991. The effect of temperature and algal biomass on bacterial production and specific growth rate in freshwater and marine habitats. Microb. Ecol. 21:99-118.

Whitton BA, 2012. Ecology of Cyanobacteria II. Their Diversity in space and time. Springer, The Netherlands: $760 \mathrm{pp}$.

Williams TJ, Wilkins D, Long E, Evans F, DeMaere MZ, Raftery MJ, Cavicchioli R, 2013. The role of planktonic Flavobacteria in processing algal organic matter in coastal East Antarctica revealed using metagenomics and metaproteomics. Environ. Microbiol. 15:1302-1317.

Winter C, Bouvier T, Weinbauer MG, Thingstad TF, 2010. Tradeoffs between competition and defense specialists among unicellular planktonic organisms: the "killing the winner" hypothesis revisited. Microbiol. Mol. Biol. R. 74:42-57.

Wintzingerode F, Göble U, Stackebrandt E, 1997. Determination of microbial diversity in environmental samples: Pitfalls of PCR-based rRNA analysis. FEMS Microbiol. Rev. 21:213-229.

Wurzbacher C, Salka I, Grossart HP, 2012. Environmental actinorhodopsin expression revealed by a new in situ filtration and fixation sampler. Environ. Microbiol. Rep. 4:491-497.

Zeder M, Peter S, Shabarova T, Pernthaler J, 2009. A small population of planktonic Flavobacteria with disproportionally high growth during the spring phytoplankton bloom in a prealpine lake. Environ. Microbiol. 11:2676-2686.

Zeng Y, Kasalický V, Šimek K, Koblížek M, 2012. Genome sequences of two freshwater betaproteobacterial isolates, $\mathrm{Lim}$ nohabitans species strains Rim28 and Rim47, indicate their capabilities as both photoautotrophs and ammonia oxidizers. J. Bacteriol. 194:6302-6303.

Zotina T, Köster O, Jüttner F, 2003. Photoheterotrophy and lightdependent uptake of organic and organic nitrogenous compounds by Planktothrix rubescens under low irradiance. Freshwater Biol. 48:1859-1872.

Zwart G, Crump B, Kamst-van Agterveld M, Hagen F, Han S, 2002. Typical freshwater bacteria: An analysis of available 16S rRNA gene sequences from plankton of lakes and rivers. Aquat. Microb. Ecol. 28:141-155.

Zwisler W, Selje N, Simon M, 2003. Seasonal patterns of the bacterioplankton community composition in a large mesotrophic lake. Aquat. Microb. Ecol. 31:211-225. 